\title{
Brick-and-Mortar Retailers: Becoming Smarter with Innovative Technologies
}

\author{
Katija Vojvodić \\ University of Dubrovnik, Department of Economics and Business Economics, Dubrovnik, Croatia
}

\begin{abstract}
Nowadays, advanced interactive in-store technologies provide brick-and-mortar retailers with a wide range of opportunities to interact with customers. Based on a comprehensive review of the academic and practitioner literature, the purpose of this paper is to advance understanding of smart, innovative technologies in brickand-mortar retail settings, and to determine a framework for further analysis. In addition, a pilot survey was conducted to gain better understanding of self-service technology from the perspective of food retailers. Despite the perceived diminishing role, brick-and-mortar retailers have the potential to be powerful players in the future of shopping. Apart from adapting to the latest technology, the key to retailers' success is introducing customers to the emerging technology within smart retail settings while encouraging their active digital engagement. Technological advancements help retailers gather various information on consumer behaviour, as well as their expectations, needs and preferences. By developing their technological capabilities, retailers will be able to create a unique in-store experience and make shopping in brick-and-mortar stores enjoyable.
\end{abstract}

\section{Keywords}

Brick-and-mortar retailers, innovative in-store technology, smart shopping, customer behaviour.

\section{Introduction}

In the present digital era, brick-and-mortar retailing is being challenged to become smarter and provide greater value to both consumers and retailers (Dacko, 2017). In particular, continual innovation and digitalization are critical when helping retailers' to create a sustainable competitive advantage (Inman \& Nikolova, 2017) and capitalise on strategic opportunities (Kim, Lee, Mun, \& Johnson, 2017). In this sense, Pantano, Priporas, \& Dennis (2018) developed the idea of smart retailing, i.e. the emerging retail scenario based on the use of innovative technologies to improve retail service and to develop innovation management strategies. Furthermore, the use of technology-enriched retail services is of great importance to improve the overall retail service quality and to create a more personalised retail experience. Consequently, it also enhances the overall retailers' performance.
In addition, the rapid growth of digital technologies and ongoing transformation in retailing sector allow for augmenting the shopping experience (Willems, Smolders, Brengman, Luyten, \& Schöning, 2017). In general, customer experience represents a means of differentiation and a challenging issue for retailers (Terblanche, 2018). In this sense, the use of radio frequency identification (RFID) technology and other smart in-store technology applications provide retailers with data on customer behaviour in real-time. However, customers often think that innovations serve primarily to the service providers to cut costs rather than to extend customer service levels (Nijssen, Schepers, \& Belanche, 2016).

Based on an extensive review of the recent literature, this paper aims to advance understanding of innovative in-store technologies in retail settings, and to determine a framework for further analysis. Therefore, the paper is structured as follows. After the introduction, the first section deals with the smart shopping whereas the second section examines innovative 
in-store technologies in the retail environment. The third section brings out the findings of the pilot survey on self-service technologies (SSTs) from the perspective of food retailers. The fourth section proposes a research agenda for further study in the context of smart innovative in-store technologies. Finally, in the last section some conclusions have been drawn upon.

\section{Smart shopping}

Nowadays, retail store operations face a variety of novel challenges and complexities (Shandong, Robb, \& DeHoratius, 2018). It can be argued that many customer-facing Internet of Things technologies have become an integral part of the retail industry. These include smart shopping carts, augmented reality, interactive displays, smart mirror interactive technology (magic mirrors or memory mirrors), RFID tags, and smart kiosks (Balaji, Kumar Roy, Sengupta, \& Chong, 2017). In the context of smart applications in the retail industry, Chaudhuri (2018) depicts smart fitting rooms, smart shelves, smart advertising using beacons, intelligent vending machines and store screening robots. In addition, Hilton, Hughes, Little, \& Marandi (2013) examine selfservice technology that replaces the customerservice employee experience with a customertechnology experience. This also raises many questions regarding the loss of jobs caused by technological change (Chessell, 2018; Nica, 2018; Grossman, 2018; Nica et al. 2018; Sorells, 2018). Generally, SSTs are mainly offered to reduce retailer costs and enhance customer's experience (Orel \& Kara, 2014). Furthermore, Djelassi, Diallo, \& Zielke (2018) found that technology experience is a driver of SST and store customers' satisfaction.

According to Hagberg, Sundstrom, \& EgelsZandén (2016), digitalization represents an ongoing transformation that is of great importance for the retail sector. Accordingly, they specify transformations associated with retailing exchanges, the nature of retail offerings, retail settings, and the actors who participate in retailing. With regard to retail innovation and the time choice for the innovation introduction, Pantano (2016) argues that the innovation success requires a deep understanding of risks and benefits of the process, as well as of the best moment for the introduction of innovation. In addition, Renko and Druzijanic (2014) highlight that innovative technology helps consumers make their shopping decisions. Moreover, technology and tools help consumers facilitate decisionmaking (Grewal, Roggeveen, \& Nordfält, 2017). Furthermore, comfortable retail environments increase both utilitarian value and hedonic value (Ainsworth \& Foster, 2017). Therefore, Kumar Roy, Balaji, Quazi, \& Quaddus (2018) stress that retail stores should focus on smart technologies that are simple, yet offer enhanced customer value through improved shopping efficiency. Similarly, Kallweit, Spreer, \& Toporowski (2014) stressed that retailers have to emphasize the service-related value of innovative technologies.

In recent years, a pleasure gather experience during the shopping activity has grown in importance in the context of brick-and-mortar shopping (Pantano \& Naccarato, 2010). Smart shopping includes consumers seeking to minimize the expenditure of time, money, or energy to gain hedonic or utilitarian value from their experience (Atkins \& Kim, 2012). Further, Kumar Roy, Balaji, Sadeque, Nguyen, \& Melewar (2017) have outlined that smart customer experience directly enhances satisfaction and reduces perceived risk towards smart retail technologies. As argued by Inman \& Nikolova (2017), new shopper-facing technologies affect shopper perceptions of the retailer and, consequently, mediate behavioural intentions.

\section{Innovative in-store technologies}

With the rapid advances in Internet technology, many retailers view Internet of Things as a potential basis for achieving sustainable competitive advantage and long-term profitability (Balaji et al., 2017). In the following, smart instore technologies such as RFID-based smart fitting rooms, smart shelves, smart shopping carts, self-checkout systems, and technology-mediated realities will be discussed.

\subsection{RFID-based smart fitting rooms}

Generally, as regards benefits of the radio frequency identification (RFID) technology, Mehrjerdi (2011) emphasizes automation, transparency, asset management, velocity, insight, traceability, security, reliability, and capability. According to Haq and Farooq (2019), an augmented fitting room is an equivalent of instore dressing room, which enables customers to try on clothes virtually instead of physically (p. 102). Wong, Leung, Guo, Zeng, \& Mok (2014) emphasize that customers who use the fitting rooms want to determine whether different outfits suit them. 
As soon as customer brings items into the fitting room, they are shown on the screen. While trying out the items, shopper does not need to exit the fitting room to collect another desired item. Instead, an alert is sent to the store attendant on their mobile device, who then brings the item (Chaudhuri, 2018). The RFID readers provide information on items taken into the fitting room and browsed through the interactive computer system (Choi, Cheung, Yang, \& Yang, 2015). Later, such information is used to formulate appropriate and sustainable retailing strategies.

As stressed by Mukherjee, Smith, \& Turri (2018), RFID-based smart fitting rooms increase and generate purchase activities only for highquality brands, whereas they are ineffective for the low-quality brands. By identifying customer behaviour in real-time, it is possible to create a more personalised retail experience (Landmark \& Sjøbakk, 2017).

\subsection{Smart shelves}

According to Gaukler \& Seifert (2007), smart shelves are retail shelves that have RFID readers built-in, and their main purpose is to prevent outof-stock situations from occurring at the shelf ( $p$. 33). Similarly, Pradhan (2007) notes that this allows the store to restock inventory on demand and avoid lost sales due to empty shelves. Chaudhuri (2018) focuses on smart shelves with digital-camera sensors and analytics technology to track shoppers' behaviour towards products on shelves and to keep track of items on the shelves.

In addition, Sanghera et al. (2007) outline the following advantages of smart-shelf system: maintaining better efficiency in inventory management, notifying store personnel of misplaced items, and determining the sale potential of an item in a timely fashion (p. 143). On the other hand, they also indicate several disadvantages, e.g. rising costs due to the need of many readers and tags, interference of signals, and inability of readers to read all items in case of densely packaging stuff on a shelf.

\subsection{Smart shopping carts}

Smart shopping carts are shopping carts or trolleys attached with a tablet (Balaji et al., 2017, p. 32). In addition, Van Hove et al. (2018) stressed that they serve as an inspiration tool. Apart from saving time and making shopping easy, smart shopping carts can help in lessening work and in making a superior shopping knowledge for the customer (Karjol, Holla, \&
Abhilash, 2018). They can retrieve and store information in real-time, answer queries, and enable check out without waiting in the line. Moreover, smart shopping carts can track consumer pathways through the store and offer functional insights into their reactions to specific displays or promotions along the way (Raju, Zhang, Sorensen, DeHerder, \& Blatt, 2011). In that context, Van Ittersum, Wansink, Pennings, \& Sheehan (2013) analysed how real-time feedback can influence customer spending and they found out that smart shopping carts increase repatronage intentions for budget shoppers while keeping them stable for nonbudget shoppers. By guiding customers through the shopping process, smart shopping carts assist customers and make the overall shopping experience easier and more enjoyable.

\subsection{Self-service checkouts}

In the context of SSTs, self-checkout systems (SCS) are becoming increasingly popular, especially in the supermarket setting. Regarding ethical acceptability, self-service checkouts were found to be the most acceptable technology-based initiative (Fullerton, Brooksbank, \& Neale, 2017). To increase retail patronage, it is very important to focus on improving self-service technology service quality (Lee \& Yang, 2013). In case of a self-service failure, customers prefer the employee to correct the problem and let them complete the transaction (Collier, Breazeale, \& White, 2017). In that sense, Wang, Harris, \& Patterson (2012) highlight the importance of preventing frequent failures and providing speedy recovery in the SST context. Therefore, retailers should install a sufficient number of user-friendly self-checkouts with attentive employees to encourage usage and reduce the perceived risk and anxiety (Kazancoglu \& Yarimoglu, 2018).

The study by Lee and Lyu (2016) reveals that only utilitarian attitudes have a significant effect on the intention to use self-service technologies. On the other hand, in a hedonic oriented selfservice environment fun alone is a significant predictor of customer enjoyment (Collier \& Barnes, 2015). Collier, Moore, Horky, \& Moore (2015) found that during the SST transaction, four situational variables, i.e. order size, wait-time tolerance, location convenience, and employee presence had a strong influence in customers' SST decisions. Additionally, Bulmer, Elms, \& Moore (2018) found that unwilling customers feel a sense 
of social obligation to use self-service checkouts at times in order to help others.

In addition to previous usage behaviour, situational factors (time pressure, basket size, coupons and queue length at the SSTs and staffed checkouts) influence customers' decisions to use SSTs (Demoulin \& Djelassi, 2016). Furthermore, SST usage intentions were positively correlated to retail patronage intentions (Lee, 2015). Study by Lee (2017) showed the inverse relationship between the need for interaction with a retail employee and the intentions to use SSTs. Further, Lee, Cho, Xu, \& Fairhurst (2010) conclude that individual differences when using the retail self-checkouts can be attributed to consumer traits that are determined by some of the demographic factors. With regard to age, older consumers have shown less experience with fewer types of SSTs; they manifest less confidence when using SST, report missing human interaction to a greater degree, and they use self-checkout less often when the additional option is available (Dean, 2008).

\subsection{Technology-mediated realities}

Technology-mediated realities mainly refer to augmented reality (AR) and virtual reality (VR). However, the boundaries between these new realities have not been clarified yet (Flavian, Ibanez-Sanchez, \& Orus, 2018). According to Martin (2018), augmented reality (AR) works by placing content produced on a computer alongside something that is real, i.e. it bridges the gap between the real world and the digital world. Although there are many types of AR display technologies, three major types include head mounted displays, handheld displays, and spatial displays (Bozkurt, 2018). Retailers use AR packaging, displays, and signage to engage customers as they shop in-store (Peddie, 2017). Poushneh \& Vasquez-Parraga (2017) show that augmented reality significantly shapes user experience and as such subsequently influences user satisfaction and users' willingness to buy goods.

On the other hand, Vazquez \& Kent (2017) note that virtual reality can be seen as a world portrayed through a three-dimensional computerised interface that mimics the environment of the real world (p. 188). In other words, the user is completely engaged in a virtual world (Toellner, 2014). The beneficial effects of VR are most marked in case of high perceived crowding (Van Kerrebroeck, Brengman, \& Willems, 2017).

\section{Self-service technology: a pilot survey}

Based on the innovative in-store technologies what were depicted in the previous sections and previous research in the field, the main objective of this pilot survey was to gain better understanding of SSTs from the perspective of food retailers. Purposive sampling technique, i.e. expert sampling was used to recruit six retail managers. As argued by Etikan, Musa, \& Alkassim (2016), expert sampling is a positive tool to use when investigating new areas of research, to garner whether or not further study would be worth the effort (p. 3). For the purpose of this paper, the author conducted e-mail interviews with experts in the field of retail selfservice technologies. The aim of the survey was to assess food retailers' perceptions of benefits and challenges associated with the use of SST systems, the current use of the systems, their experiences in adopting these systems as well as their plans for the future. In that context, particular emphasis was put on self-service checkouts as a widespread form of SSTs across the retail sector globally.

The interview questions were embedded in the e-mail message and sent to retail managers. In addition to questions, instructions to the participants on completing the interview were also included. Furthermore, questions were concise in order to avoid any miscommunication and misinterpretation. None of the participants asked for additional clarifications or further explanations. Therefore, there was no need for follow-up questions. Four participants responded before the deadline date, whereas two reminders were sent to the remaining participants who responded afterwards. Qualitative data were collected from November 2018 to January 2019 using e-mail interviews with six retail managers from the top ten leading food retailers in Croatia. Two of the managers interviewed held a managing or regional director position; one participant was a board member, whereas three of them held a head of store position. The first part of the interview included the data on retailers (i.e. origin, market and retail formats operated). Table 1 shows sample characteristics.

The second part of the interview was dealing with retailers' perceptions of SST systems, their experiences and plans for the future. All retail 
managers that were interviewed were aware of numerous benefits associated with the use of SST systems. In this sense, retailers emphasized the following benefits: achieving competitive advantage, increasing service quality and customer satisfaction, improving productivity, increasing service efficiency, enhancing the overall shopping experience, redeploying employees to other areas, reduced costs, and reduced waiting time. In addition, management also commented that SST systems could positively affect their business.

Table 1 Sample characteristics

\begin{tabular}{c|c|c|c}
\hline Retailer & Origin & Market & Retail formats \\
\hline Retailer 1 & Domestic & Local & $\begin{array}{c}\text { Hypermarkets, } \\
\text { supermarkets, } \\
\text { convenience } \\
\text { stores }\end{array}$ \\
\hline Retailer 2 & Foreign & National & $\begin{array}{c}\text { Hypermarkets, } \\
\text { supermarkets }\end{array}$ \\
\hline Retailer 3 4 & Domestic & National & $\begin{array}{c}\text { Hypermarkets, } \\
\text { supermarkets, } \\
\text { convenience } \\
\text { stores }\end{array}$ \\
\hline Retailer 5 & Foreign & Regional & $\begin{array}{c}\text { Supermarkets, } \\
\text { convenience } \\
\text { stores }\end{array}$ \\
\hline Retailer 6 & Domestic & Regional & $\begin{array}{c}\text { Hypermarkets, } \\
\text { supermarkets }\end{array}$ \\
\hline
\end{tabular}

Source: Author's research

With regard to the use of SST systems, all retail managers interviewed recognized the importance of implementing SST systems in their stores. In terms of two main types of SST installations, significant differences can be observed. On the one hand, all six retail managers reported that they provided interactive self-service installations, mainly self-service weighing machines and price checkers. On the other hand, only one retailer (retailer No. 3) confirmed the use of installed self-service checkout machines in some stores. It can be noted that diffusion of selfservice checkouts is quite limited in food retailing business in Croatia. As regards experiences when adopting self-service checkout machines, retailer No. 3 expressed the overall satisfaction with the system. As regards customer adoption, retail manager stated that approximately one-third of customers used the self-service checkout machines in their stores. In terms of challenges associated with the use of SST systems, four managers pointed out consumers' willingness to use the self-service checkouts. According to two managers interviewed, encouraging customers to start using self-service checkouts is crucial in retail settings. In addition, all retail managers that were interviewed stressed the importance of welltrained employees assisting customers when using SST systems.

In terms of their plans for the future, all of the retail managers stated that they are familiar with numerous advancements in the field of innovative in-store technologies. However, only two retailers (retailer No. 2 and retailer No. 3) were keen to point out their intention and further spread of selfservice checkout machines. On the other hand, other retailers were not enthusiastic about the adoption of self-service checkout machines in their retail stores and they agreed that these machines were not priorities for their businesses. Two retailers argued that customers were not ready to adopt self-service checkouts and pointed out frequent technical failures of self-service checkout machines. Further, one retailer emphasized the role of sales personnel and the aim of creating relationship with their customers. Likewise, one retailer stressed the importance of enhancing social interaction in stores and, in particular, in the context of elderly consumers. In addition, three retailers also highlighted the issue of shoplifting and the rise of supermarket selfcheckout scams as major obstacles to adoption of self-service checkouts.

\section{Smart in-store technology: Research propositions}

As noted previously, current retailing is moving to a smart perspective (Pantano et al., 2018). However, the literature on advanced, innovative technologies in retail settings and customerrelated behaviour is still rather limited. In that sense, Foroudi, Gupta, Sivarajah, \& Broderick (2018) highlight that previous work failed to address the influence of smart technology usage, combined with behavioural intention of the customer, on the dynamics and experience of customers. Therefore, further research should deal with the challenges emerging from the adoption of such smart technologies. The pilot survey presented in the third section is limited due to its sample size and, therefore, it is insufficient for generalizing. However, it does provide a starting point for future analysis. Although it is evident that experts in the field recognize numerous 
advantages of retail self-service technologies, customer feedback is missing. Consequently, future work should concentrate on the effects of smart technology on customers' experience. In particular, it is important to identify how smart technologies influence shopping patterns and consumers' experiences of the in-store environment. Moreover, the introduction of emerging in-store technologies requires the identification of customer clusters based on the usage of these technologies.

In the context of technologically sophisticated retail services, concerns have arisen with regard to the customers' adoption and their psychological reactions towards smart retail technologies (Kumar Roy et al., 2017). More work should be done to find out how the introduction of advanced technologies, such as smart fitting rooms, technology-mediated realities, smart shopping carts, or self-checkout systems modifies the retailing context and affects the overall consumers shopping experience. Further, Priporas, Stylos, \& Fotiadis (2017) revealed that consumers expect the technology to enable them to make informed shopping decisions. Consequently, in a brick-andmortar retail context it is crucial to determine how smart technologies affect the traditional customer decision-making process. Additionally, consumers' expectations of interactions in the smart retailing setting are also worth examining.

Further research is also needed to determine customers' attitude and preferences towards different smart technologies in the retail sector. Moreover, it is important to examine how the use of smart in-store technologies enhances customer experience and loyalty. In addition, their acceptance of and resistance to these technologies are questions in need of further investigation. In particular, these considerations could be examined in terms of various generational cohorts (e.g., Baby Boomers, generation $\mathrm{X}$, generation $\mathrm{Y}$, and generation Z). Additionally, Kumar Roy et al. (2017) suggest that smart customer experience directly enhances satisfaction and reduces perceived risk. Consequently, further studies should also look into the impact of innovative smart technologies on customers' satisfaction and willingness to buy goods.

\section{Conclusion}

The phenomenon of digitalization is strongly reshaping the overall brick-and-mortar retail settings. Nowadays, smart technologies provide a wide range of opportunities to interact with customers in retailing contexts. Moreover, new interactive technologies provide brick-and-mortar retailers with comprehensive insight into new information on consumer behaviour, as well as their expectations, needs and preferences. In that context, particular importance should be placed on the introduction of innovative smart technologies in the physical retail environment. Despite the perceived diminishing role, brick-and-mortar retailers have the potential to be powerful players in the future of shopping. By developing their technological capabilities, retailers will be able to make shopping in brick-and-mortar stores enjoyable and to create a unique in-store experience.

One of their main goals should be introducing customers to interactive technologies within smart retail settings to encourage their active digital engagement. Technological advancements help retailers gather various customer-related information and identify their shopping preferences and purchasing trends. Investments in smart innovative technologies create differentiation in brick-and-mortar retail settings and enable individualization and personalization of consumers' shopping experiences. Consequently, gaining a better understanding of the smart shopper behaviour will enable retailer managers, marketers, retail store personnel, and designers of technological interfaces to more accurately target their consumers. Additionally, consumers' digital engagement may lead towards creating a unique experience and customer loyalty.

Based on a comprehensive review of the academic and practitioner literature, the paper synthesizes current findings to contribute to the existing body of knowledge on the usage of smart, innovative technologies in brick-and-mortar retail settings. In addition, it may present a starting point for better understanding and researching the phenomenon of digital transformation in brickand-mortar retail settings. As noted previously, the literature offers limited understanding of consumer behaviour and attitude towards the usage of in-store innovative technologies. On a wider level, future research needs to be carried out to identify how the introduction of advanced technologies modifies the brick-and-mortar retailing context. Overall, more research is still needed to analyse the challenges emerging from the adoption of smart technologies in brick-andmortar shopping contexts. In particular, an important issue to examine is how innovative 
technologies affect customers' in-store experience and to find out their expectations from the interactions in such smart retailing setting.sm

\section{References}

Ainsworth, J., \& Foster, J. (2017). Comfort in brick and mortar shopping experiences: Examining antecedents and consequences of comfortable retail experiences. Journal of Retailing and Consumer Services, 35, 27-35. https://doi.org/10.1016/i.jretconser.2016.11.005

Atkins, K. G., \& Kim, Y.-K. (2012). Smart shopping: conceptualization and measurement. International Journal of Retail \& Distribution Management, 40 (5), 360-375.

https://doi.org/10.1108/09590551211222349

Balaji, M. S., Kumar Roy, S., Sengupta, A., \& Chong, A. (2017). User Acceptance of loT Applications in Retail Industry. In I. Lee (Ed.), The Internet of Things in the Modern Business Environment (pp. 28-49). Hershey: IGI Global.

https://doi.org/10.4018/978-1-5225-2104-4.ch002

Bozkurt, A. (2018). Augmented Reality With Mobile and Ubiquitous Learning: Immersive, Enriched, Situated, and Seamless Learning Experience. In Information Resources Management Association, Virtual and Augmented Reality: Concepts, Methodologies, Tools, and Application (pp. 603-617). Hershey: IGI Global https://doi.org/10.4018/978-1-5225-5469-1.ch029

Bulmer, S., Elms, J., \& Moore, S. (2018). Exploring the adoption of self-service checkouts and the associated social obligations of shopping practices. Journal of Retailing and Consumer Services, 42, 107-116. https://doi.org/10.1016/j.jretconser.2018.01.016

Chaudhuri, A. (2018). Internet of Things, for Things, and by Things. Boca Raton: CRC Press. https://doi.org/10.1201/9781315200644

Chessell, D. (2018). The Jobless Economy in a Post-Work Society: How Automation Will Transform the Labor Market. Psychosociological Issues in Human Resource Management, 6 (2), 74-79. https://doi.org/10.22381/pihrm6220187

Choi, S. H., Cheung, H. H., Yang, B., \& Yang, Y. X. (2015). Item-Level RFID for Retail Business Improvement. In I. Lee (Ed.), RFID Technology Integration for Business Performance Improvement (pp. 1-26). Hershey: IGI Global. https://doi.org/10.4018/978-1-4666-6308-4.ch001

Collier, J. E. \& Barnes, D. C. (2015). Self-service delight: Exploring the hedonic aspects of self-service. Journal of Business Research, 68 (5), 986-993. https://doi.org/10.1016/j.jbusres.2014.09.036

Collier, J. E., Moore, R. S., Horky, A., \& Moore, M. L. (2015). Why the little things matter: Exploring situational influences on customers' self-service technology decisions. Journal of Business Research, 68 (3), 703710. https://doi.org/10.1016/j.jbusres.2014.08.001

Collier, J. E., Breazeale, M., \& White, A. (2017). Giving back the "self" in self service: customer preferences in self-service failure recovery. Journal of Services Marketing, 31 (6), 604-617. https://doi.org/10.1108/JSM-07-2016-0259
Dacko, S. G. (2017). Enabling smart retail settings via mobile augmented reality shopping apps. Technological Forecasting and Social Change, 124, 243-256. https://doi.org/10.1016/j.techfore.2016.09.032

Dean, D. H. (2008). Shopper age and the use of self-service technologies. Managing Service Quality: An International Journal, 18 (3), 225-238. https://doi.org/10.1108/09604520810871856

Demoulin, N. T. M, \& Djelassi, S. (2016). An integrated model of self-service technology (SST) usage in a retail context. International Journal of Retail \& Distribution Management, 44 (5), 540-559. https://doi.org/10.1108/IJRDM-08-2015-0122

Djelassi, S., Diallo, M. F., \& Zielke, S. (2018). How selfservice technology experience evaluation affects waiting time and customer satisfaction? A moderated mediation model. Decision Support Systems, 111, 3847.

https://doi.org/10.1016/j.dss.2018.04.004

Etikan, I., Musa, S. A., \& Alkassim, R. S. (2016). Comparison of Convenience Sampling and Purposive Sampling. American Journal of Theoretical and Applied Statistics, 5 (1), 1-4. https://doi.org/10.11648/j.ajtas.20160501.11

Flavian, C., Ibanez-Sanchez, S., \& Orus, C. (2018). The impact of virtual, augmented and mixed reality technologies on the customer experience. Journal of Business Research. https://doi.org/10.1016/i.jbusres.2018.10.050

Foroudi, P., Gupta, S., Sivarajah, U., \& Broderick, A. (2018). Investigating the effects of smart technology on customer dynamics and customer experience. Computers in Human Behavior, 80, 271-282. https://doi.org/10.1016/j.chb.2017.11.014

Fullerton, S., Brooksbank, R., \& Neale, L. (2017). Consumer perspectives on the ethics of an array of technology-based marketing strategies: An exploratory study. Asia Pacific Journal of Marketing and Logistics, 29 (5), 1079-1096.

https://doi.org/10.1108/APJML-09-2016-0179

Gaukler, G. M., \& Seifert, R. W. (2007). Applications of RFID in Supply Chains. In H. Jung, F. F. Chen \& B. Jeong (Eds.), Trends in Supply Chain Design and Management: Technologies and Methodologies (pp. 2948). London: Springer-Verlang. https://doi.org/10.1007/978-1-84628-607-0 2

Grewal, D., Roggeveen, A. L., \& Nordfält, J. (2017). The Future of Retailing. Journal of Retailing, 93 (1), 1-6. https://doi.org/10.1016/j.jretai.2016.12.008

Grossman, T. (2018). The Rise of an Automated Jobless Society: Do Cutting-Edge Technologies Expel Workers Swifter than the Economy Can Identify New Jobs for Them?. Psychosociological Issues in Human Resource Management, 6 (2), 62-67. https://doi.org/10.22381/pihrm6220185

Hagberg, J., Sundstrom, M., \& Egels-Zandén, N. (2016). The digitalization of retailing: an exploratory framework. International Journal of Retail \& Distribution Management, 44 (7), 694-712. https://doi.org/10.1108/lJRDM-09-2015-0140

Haq, I., \& Farooq, A. M. (2019). TryOn: An Augmented Reality Fitting Room. In S. Umair \& M. Y. Shah (Eds.), Mobile Devices and Smart Gadgets in Human Rights (pp. 98-131). Hershey: IGI Global. https://doi.org/10.4018/978-1-5225-6939-8.ch005 
Hilton, T., Hughes, T., Little, E., \& Marandi, E. (2013). Adopting self-service technology to do more with less. Journal of Services Marketing, 27 (1), 3-12. https://doi.org/10.1108/08876041311296338

Inman, J. J., \& Nikolova, H. (2017). Shopper-Facing Retail Technology: A Retailer Adoption Decision Framework Incorporating Shopper Attitudes and Privacy Concerns. Journal of Retailing, 93 (1), 7-28. https://doi.org/10.1016/j.jretai.2016.12.006

Kallweit, K., Spreer, P., \& Toporowski, W. (2014). Why do customers use self-service information technologies in retail? The mediating effect of perceived service quality. Journal of Retailing and Consumer Services, 21 (3), 268-276. https://doi.org/10.1016/j.jretconser.2014.02.002

Karjol, S., Holla, A. K., \& Abhilash, C. B. (2018). An IOT Based Smart Shopping Cart for Smart Shopping. In T.N. Nagabhushan, V. N. Manjunath Aradhya, P. Jagadeesh, S. Shukla, Chayadevi, M. L. (Eds.), Cognitive Computing and Information Processing (pp. 373-385). Singapore: Springer Verlag. https://doi.org/10.1007/978-981-10-9059-2 33

Kazancoglu, I., \& Yarimoglu, E. K. (2018). How food retailing changed in Turkey: spread of self-service technologies. British Food Journal, 120 (2), 290-308. https://doi.org/10.1108/BFJ-03-2017-0189

Kim, H.-Y., Lee, J. Y., Mun, J. M., \& Johnson, K. K. P. (2017). Consumer adoption of smart in-store technology: assessing the predictive value of attitude versus beliefs in the technology acceptance model. International Journal of Fashion Design, Technology and Education, 10 (1), 26-36. https://doi.org/10.1080/17543266.2016.1177737

Kumar Roy, S., Balaji, M. S., Sadeque, S., Nguyen, B., \& Melewar, T. C. (2017). Constituents and consequences of smart customer experience in retailing. Technological Forecasting and Social Change, 124, 257-270. https://doi.org/10.1016/j.techfore.2016.09.022

Kumar Roy, S., Balaji, M. S., Quazi, A., \& Quaddus, M. (2018). Predictors of customer acceptance of and resistance to smart technologies in the retail sector. Journal of Retailing and Consumer Services, 42, 147160. https://doi.org/10.1016/j.jretconser.2018.02.005

Landmark, A. D., \& Sjøbakk, B. (2017). Tracking customer behaviour in fashion retail using RFID. International Journal of Retail \& Distribution Management, 45 (7/8), 844-858. https://doi.org/10.1108/IJRDM-10-2016-0174

Lee, H.-J., Cho, H. J., Xu, W., \& Fairhurst, A. (2010). The influence of consumer traits and demographics on intention to use retail self-service checkouts. Marketing Intelligence \& Planning, 28 (1), 46-58. https://doi.org/10.1108/02634501011014606

Lee, H.-J., Yang, K. (2013). Interpersonal service quality, self-service technology (SST) service quality, and retail patronage. Journal of Retailing and Consumer Services, 20 (1), 51-57. https://doi.org/10.1016/j.jretconser.2012.10.005

Lee, H.-J. (2015). Consumer-to-store employee and consumer-to-self-service technology (SST) interactions in a retail setting. International Journal of Retail \& Distribution Management, 43 (8), 676-692. https://doi.org/10.1108/IJRDM-04-2014-0049
Lee, H.-J., \& Lyu, J. (2016). Personal values as determinants of intentions to use self-service technology in retailing. Computers in Human Behavior, 60, 322-332. https://doi.org/10.1016/j.chb.2016.02.051

Lee, H.-J. (2017). Personality determinants of need for interaction with a retail employee and its impact on selfservice technology (SST) usage intentions. Journal of Research in Interactive Marketing, 11 (3), 214-231. https://doi.org/10.1108/JRIM-04-2016-0036

Martin, B. S. (2018). Augmented Reality. Chicago: Norwood House Press.

Mehrjerdi, Y. Z. (2011). RFID and its benefits: a multiple case analysis. Assembly Automation, 31 (3), 251-262. https://doi.org/10.1108/01445151111150596

Mukherjee, A., Smith, R. J., \& Turri, A. M. (2018). The smartness paradox: the moderating effect of brand quality reputation on consumers' reactions to RFIDbased smart fitting rooms. Journal of Business

Research, 92, 290-299. https://doi.org/10.1016/i.jbusres.2018.07.057

Nica, E. (2018). Will Robots Take the Jobs of Human Workers? Disruptive Technologies that May Bring About Jobless Growth and Enduring Mass Unemployment. Psychosociological Issues in Human Resource Management, 6 (2), 56-61. https://doi.org/10.22381/pihrm6220184

Nica, E., Manole, C., \& Stan, C. I. (2018). A Laborless Society? How Highly Automated Environments and Breakthroughs in Artificial Intelligence Bring About Innovative Kinds of Skills and Employment Disruptions, Altering the Nature of Business Process and Affecting the Path of Economic Growth. Journal of SelfGovernance and Management Economics, 6 (4), 25-30. https://doi.org/10.22381/isme6420184

Nijssen, E. J., Schepers, J. J. L., \& Belanche, D. (2016). Why did they do it? How customers' self-service technology introduction attributions affect the customerprovider relationship. Journal of Service Management, 27 (3), 276-298. https://doi.org/10.1108/JOSM-08-2015-0233

Orel, F. D., \& Kara, A. (2014). Supermarket self-checkout service quality, customer satisfaction, and loyalty: Empirical evidence from an emerging market. Journal of Retailing and Consumer Services, 21 (2), 118-129. https://doi.org/10.1016/j.jretconser.2013.07.002

Pantano, E., \& Naccarato, G. (2010). Entertainment in retailing: The influences of advanced technologies. Journal of Retailing and Consumer Services, 17 (3), 200-204. https://doi.org/10.1016/j.jretconser.2010.03.010

Pantano, E. (2016). Benefits and risks associated with time choice of innovating in retail settings. International Journal of Retail \& Distribution Management, 44 (1), 5870. https://doi.org/10.1108/IJRDM-03-2015-0047

Pantano, E., Priporas, C. V., \& Dennis, C. (2018). A new approach to retailing for successful competition in the new smart scenario. International Journal of Retail \& Distribution Management, 46 (3), 264-282. https://doi.org/10.1108/IJRDM-04-2017-0080

Peddie, J. (2017). Augmented Reality: Where We Will All Live. Berlin: Springer. https://doi.org/10.1007/978-3-319-54502-8 
Poushneh, A., \& Vasquez-Parraga, A. Z. (2017). Discernible impact of augmented reality on retail customer's experience, satisfaction and willingness to buy. Journal of Retailing and Consumer Services, 34, 229-234. https://doi.org/10.1016/j.jretconser.2016.10.005

Pradhan, S. (2007). Retailing Management: Text and cases. New Delhi: Tata McGraw-Hill.

Priporas, C.-V., Stylos, N., \& Fotiadis, A.K. (2017). Generation Z consumers' expectations of interactions in smart retailing: A future agenda. Computers in Human Behavior, 77, 374-381. https://doi.org/10.1016/j.chb.2017.01.058

Raju, J. J., Zhang, Z., Sorensen, H., DeHerder, R., \& Blatt, D. (2011). Strategies for Success in Retail (Collection). Pearson Education.

Renko, S., \& Druzijanic, M. (2014). Perceived usefulness of innovative technology in retailing: Consumers' and retailers' point of view. Journal of Retailing and Consumer Services, 21 (5), 836-843. https://doi.org/10.1016/i.jretconser.2014.02.015

Sanghera, P., Thornton, F., Haines, B., Kleinschmidt, J., Das, A. M., Bhargava, H., \& Campbell, A. (2007). How to Cheat at Deploying and Securing RFID. Burlington: Syngress Publishing.

Shandong, M., Robb, D. J., \& DeHoratius, N. (2018). Retail store operations: Literature review and research directions. European Journal of Operational Research, 265 (2), 399-422. https://doi.org/10.1016/j.ejor.2017.07.003

Sorells, B. (2018). Will Robotization Really Cause Technological Unemployment? The Rate and Extent of Potential Job Displacement Caused by Workplace Automation. Psychosociological Issues in Human Resource Management, 6 (2), 68-73. https://doi.org/10.22381/pihrm6220186

Terblanche, N. S. (2018). Revisiting the supermarket instore customer shopping experience. Journal of Retailing and Consumer Services, 40, 48-59. https://doi.org/10.1016/j.jretconser.2017.09.004

Toellner, J. (2014). Mobile services in retail and their influence on customer satisfaction. Hamburg: Diplomica Verlag.

\section{凶 Correspondence}

\section{Katija Vojvodić}

University of Dubrovnik, Department of Economics and

Business Economics

Lapadska obala 7, 20000 Dubrovnik, Croatia

E-mail: katija.vojvodic@unidu.hr
Van Hove, S., De Letter, J., De Ruyck, O., Conradie, P., All, A., Saldien, J., \& De Marez, L. (2018). HumanComputer Interaction to Human-Computer-Context Interaction: Towards a Conceptual Framework for Conducting Users Studies for Shifting Interfaces. In A. Marcus \& W. Wang (Eds.), Design, User Experience, and Usability: Theory and Practice (pp. 277-293). Heidelberg: Springer International Publishing. https://doi.org/10.1007/978-3-319-91797-9 20

Van Ittersum, K., Wansink, B., Pennings, J. M. E., \& Sheehan, D. (2013). Smart Shopping Carts: How RealTime Feedback Influences Spending. Journal of Marketing, 77 (6), 21-36. https://doi.org/10.1509/jm.12.0060

Van Kerrebroeck, H., Brengman, M., \& Willems, K. (2017). Escaping the crowd: An experimental study on the impact of a Virtual Reality experience in a shopping mall. Computers in Human Behavior, 77, 437-450. https://doi.org/10.1016/j.chb.2017.07.019

Vazquez, D., \& Kent, A. (2017). Online retail design. In A. Petermans \& A. Kent (Eds.), Retail Design: Theoretical Perspectives (pp. 174-196). New York: Routledge.

Wang, C., Harris, J., \& Patterson, P. G. (2012). Customer choice of self-service technology: the roles of situational influences and past experience. Journal of Service Management, 23 (1), 54-78. https://doi.org/10.1108/09564231211208970

Willems, K., Smolders, A., Brengman, M., Luyten, K., \& Schöning, J. (2017). The path-to-purchase is paved with digital opportunities: An inventory of shopperoriented retail technologies. Technological Forecasting and Social Change, 124, 228-242.

https://doi.org/10.1016/j.techfore.2016.10.066

Wong, W. K., Leung, S. Y. S., Guo, Z. X., Zeng, Z. H., \& Mok, P. Y. (2014). Intelligent apparel product crossselling using radio frequency identification (RFID) technology for fashion retailing. In W. K. Wong \& Z. X. Guo (Eds.), Fashion Supply Chain Management Using Radio Frequency Identification (RFID) Technologies (pp. 159-186). Cambridge: Woodhead Publishing https://doi.org/10.1533/9780857098115.159 